\title{
As Clorofilas
}

\author{
The Chlorophylls
}

\author{
Nivia Maria Streit ${ }^{1}$ Liana Pedrolo Canterle $^{1}$ \\ Marta Weber do Canto² Luísa Helena Hychecki Hecktheuer²
}

\section{- REVISÃO BIBLIOGRÁFICA -}

\section{RESUMO}

As clorofilas são pigmentos verdes, comuns em todas as células fotossintéticas. Por sua estrutura química ser instável, são facilmente degradadas, resultando em produtos de decomposição que modificam a percepção e qualidade dos alimentos. Esta revisão trata dos vários fatores que interferem na degradação das clorofilas, como a luz, radiação, calor, ácidos, oxigênio, alteração enzimática e interação com outros pigmentos. Também, outro aspecto a ser abordado é a utilização das clorofilas como corantes, através da formação de complexos que tornam esses pigmentos mais estáveis à decomposição.

Palavras-chave:pigmentos vegetais, feofitinas, feoforbídeos, degradação.

\section{ABSTRACT}

The Chlorophylls are a common green pigment to all photosynthetic cells. They are easily degraded, because of their unstable chemical structure. Degradation results in products alter the perception and quality of foods. This review discusses the various factors, that interfere on chlorophyll degradation such as light, irradiation, heat, acids, oxygen, enzymatical alteration and the interaction with other pigments. Also, the other topic that was mentioned the utilization of the chlorophylls as dyes through a complex formation that make this pigment more stable to degradation.

Key words: pigments, pheophytins, pheophorbides, degradation.

\section{INTRODUÇÃO}

As clorofilas são os pigmentos naturais mais abundantes presentes nas plantas e ocorrem nos cloroplastos das folhas e em outros tecidos vegetais. Estudos em uma grande variedade de plantas caracterizaram que os pigmentos clorofilianos são os mesmos. As diferenças aparentes na cor do vegetal são devidas à presença e distribuição variável de outros pigmentos associados, como os carotenóides, os quais sempre acompanham as clorofilas (VON ELBE, 2000).

O nome clorofila foi proposto por Pelletier e Caventou, em 1818, para designar a substância verde que se podia extrair das folhas com o auxílio do álcool. Atualmente os pigmentos clorofilianos são de grande importância comercial, podendo ser utilizados tanto como pigmentos quanto como antioxidantes. Esta revisão discutirá vários fatores relacionados às clorofilas como suas características físicas, efeitos da luz e radiação, seu uso como corante em alimentos, fatores que interferem na formação de compostos de degradação, o processamento em indústria de alimentos e o seu metabolismo.

\footnotetext{
${ }^{1}$ Alunos do Programa de Pós-graduação em Ciência e Tecnologia de Alimentos, Universidade Federal de Santa Maria (UFSM), Brasil. E-mail: niviast@mail.ufsm.br. Autor para correspondência.

${ }^{2}$ Doutor, Professores do Departamento de Tecnologia e Ciência dos Alimentos, Centro de Ciências Rurais, UFSM, Brasil.
} 


\section{A clorofila e os vegetais}

Os pigmentos fotossintéticos presentes e a sua abundância variam de acordo com a espécie. A clorofila $a$ ( $\mathrm{Chl}$ a) está presente em todos os organismos que realizam fotossíntese oxigênica. As bactérias fotossintetizantes são desprovidas de clorofila $a$ e possuem em seu lugar a bacterioclorofila como pigmento fotossintético. A Chl a é o pigmento utilizado para realizar a fotoquímica (o primeiro estágio do processo fotossintético), enquanto que os demais pigmentos auxiliam na absorção de luz e na transferência da energia radiante para os centros de reação, sendo assim chamados de pigmentos acessórios. Os principais pigmentos acessórios também incluem outros tipos de clorofilas: Chl $b$, presente em vegetais superiores, algas verdes e algumas bactérias; Chl c, em feofitas e diatomáceas; e Chl $d$, em algas vermelhas (TAIZ \& ZIEGER, 2004).

As clorofilas são moléculas formadas por complexos derivados da porfirina, tendo como átomo central o Mg (magnésio) (figura 1). Esse composto é uma estrutura macrocíclica assimétrica totalmente insaturada constituída por quatro anéis de pirrol. Esses anéis numeram-se de l a 4 ou de "a” a "d", de acordo com o sistema de numeração de Fisher (SCHOEFS, 2002). As clorofilas $a$ e $b$ encontram-se na natureza numa proporção de 3:1, respectivamente, e diferem nos substituintes de carbono C-3. Na clorofila $a$, $o$ anel de porfirina contém um grupo metil (-CH3) no C-3 e a clorofila $b$ (considerada um pigmento acessório) contém um grupo aldeído (-CHO), que substitui o grupo metil- $\mathrm{CH}_{3} \mathrm{~A}$ estabilidade da clorofila $b$ deve-se ao efeito atrativo de elétrons de seu grupo aldeído no C-3 (VON ELBE, 2000). A clorofila $b$ é sintetizada através da oxidação do grupo metil da clorofila $a$ para um grupo aldeído. No entanto, muitos estudos têm sido realizados para elucidar a biossíntese da clorofila $b$, mas as rotas para a formação da clorofila $b$ ou das proteínas envolvidas ainda não foram elucidadas (TANAKA et al., 1998). A clorofila b é convertida em clorofila $a$ através de uma enzima chamada clorofila $a$ oxigenase, que catalisa a conversão do grupo metil ao grupo aldeído (XU et al., 2001). A estrutura química da clorofila está representada na figura 1.

As clorofilas localizam-se nos cloroplastos, sendo esta organela o continente da fotossíntese, isto é, onde ocorrem as duas reações importantes: a fotoquímica, nas membranas dos tilacóides e a bioquímica, no estroma do cloroplasto. Tais organelas, além das clorofilas, contêm outros pigmentos chamados acessórios, como os carotenóides (carotenos e xantofilas). As ligações entre as moléculas de clorofilas são muito frágeis (não-covalentes), rompendo-se com facilidade ao macerar o tecido em solventes orgânicos. O caráter hidrofílico/hidrofóbico de uma substância influi diretamente na escolha do melhor solvente para a sua extração. Os solventes polares como a acetona, o metanol, o etanol, o acetato de etila, a piridina e a dimetilformamida são os mais eficazes para a extração completa das clorofilas. Os solventes apolares como o hexano e o éter de petróleo são os menos eficazes. No caso das clorofilas $a e b, o$ aumento da polaridade da clorofila $b$ em relação à clorofila $a$ deve-se ao substítuinte aldeído (VON ELBE, 2000; MUSSI, 2003). Os dois produtos da degradação da clorofila $a$, o feoforbídeo $a$ e a feofítina $a$, podem interferir na determinação da clorofila $a$ ao absorverem luz e fluorescerem na mesma região do espectro. Se esses feopigmentos estiverem presentes na amostra, poderão ocorrer erros significativos na concentração de clorofila $a$ (BARROSO, 1998).

\section{Efeitos da luz}

Os pigmentos envolvidos na fotossíntese são as clorofilas $a$ e $b$, os carotenóides e as ficobilinas. A clorofila $b$, os carotenóides e as ficobilinas constituem os chamados pigmentos acessórios. A energia absorvida pelos pigmentos é transferida para sítios bem definidos, localizados sobre as membranas tilacóides, os chamados centros de reação. Há dois centros de reação, um deles absorvendo em 680nm e outro em 700nm, os quais interagem entre si através de transportadores de elétrons. É a partir da molécula de clorofila, a qual absorve em 680nm no espectro visível, que os elétrons oriundos da água são transferidos para a cadeia transportadora de elétrons da fotossíntese (KLUGE, 2004).

As plantas utilizam-se da radiação fotossinteticamente ativa (RFA ou PAR) que está compreendida entre 390 e 760nm (a chamada luz visível). Cada molécula de clorofila pode absorver apenas 1 quantum de energia de cada vez, o que causa excitação de um determinado elétron de um dos átomos da molécula. Os elétrons que estão em orbitais no estado estável do átomo recebem a energia e podem se deslocar para orbitais mais distantes do núcleo, a uma distância que é proporcional à energia de um fóton que absorveu. A molécula do pigmento encontra-se, então, no estado excitado, e é esta energia de excitação que é usada na fotossíntese. As clorofilas e outros pigmentos permanecem no estado excitado por períodos muito curtos (l bilionésimo de segundo $=10^{-9}$ ) e a energia é perdida por calor ou por fluorescência (ROMANO, 2001).

O estresse provocado na planta pela luz é frequente sob condições tropicais, e a concentração de clorofilas e carotenóides são indicadores da 


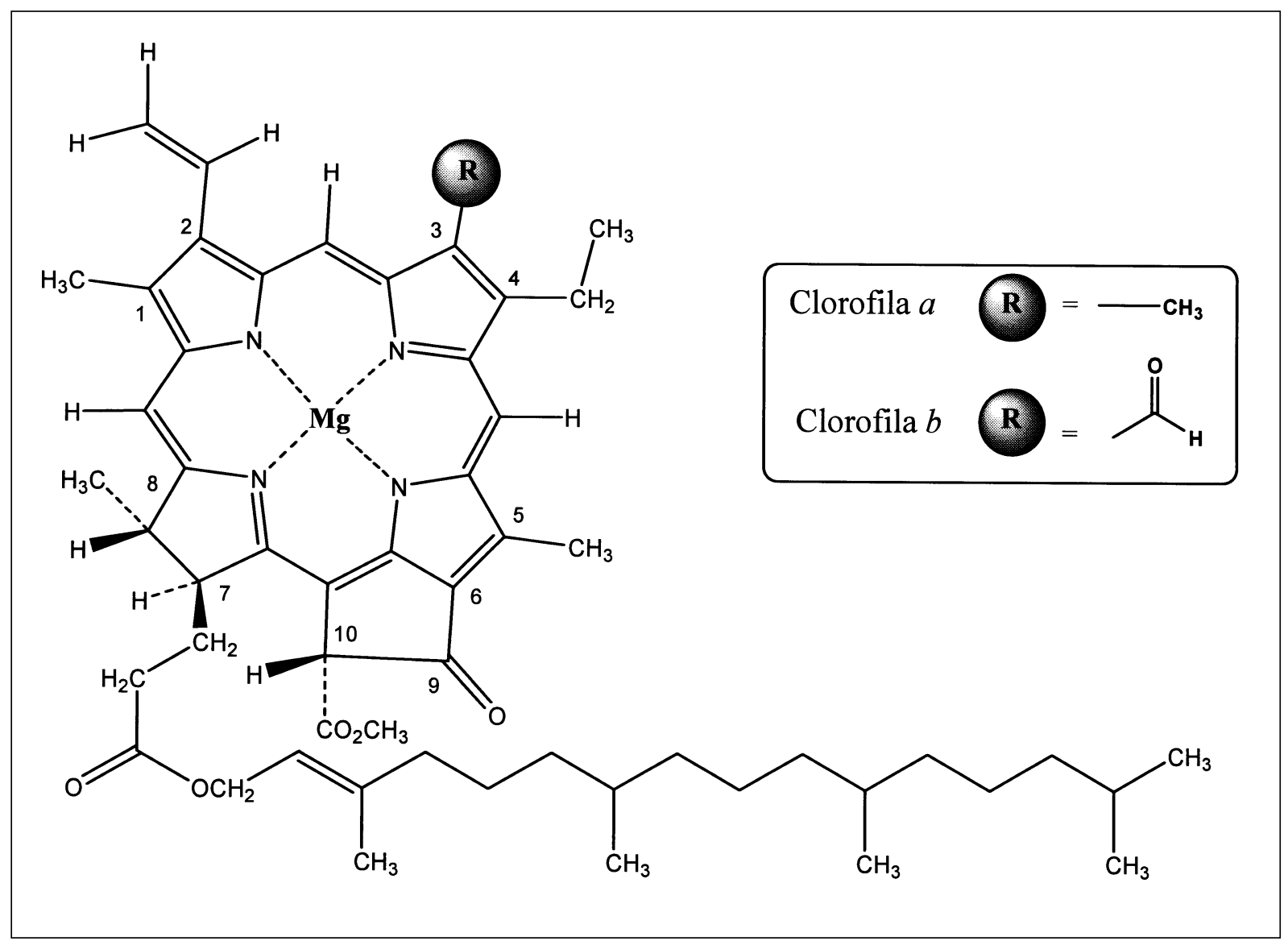

Figura 1 - Estrutura química da clorofila $a$ e clorofila $b$.

suscetibilidade da planta à intensidade da luz (VIEIRA, 1996). As clorofilas tendem a ser foto-oxidadas sob alta irradiação e, devido aos carotenóides poderem prevenir a foto-oxidação das clorofilas, a relação entre as clorofilas e carotenóides pode ser usada como um indicador potencial de perdas foto-oxidativas causadas por fortes irradiações (HENDRY \& PRICE, 1993).

As folhas alteram sua morfologia e composição, adaptativamente, respondendo à luz do meio. A luz tem o efeito de retardar a deterioração de clorofilas e proteínas. A perda das clorofilas no escuro é impedida pela cicloheximina, um inibidor da síntese de proteínas pelos ribossomas citoplasmáticos. As clorofilas são rapidamente degradadas nas folhas sob total escuridão, no entanto, sua decomposição é acentuadamente atrasada através da incidência de luz branca fraca $\left(0,5 \mu \mathrm{mol}\right.$ fótons $\left.\mathrm{m}^{-2} \mathrm{~s}^{-1}\right)$ (OKADA et al., 1992).

O excesso de luz pode inibir a fotossíntese através de dois processos: foto-inibição e foto- oxidação. A foto-inibição envolve danos aos centros de reação, especialmente FSII (fotosistema II), quando eles são superexcitados. No Fotosistema II, ocorre perda da proteína $(\mathrm{Dl})$ envolvida na transferência de elétrons entre P680 (Centro de reação do FSII) e PQ (Plastoquinona). Esta proteína pode ser recuperada posteriormente (processo reversível). A foto-oxidação é um processo irreversível e envolve diretamente os pigmentos receptores de luz, os quais, ao absorverem muita luz, ficam muito tempo excitados e interagem com o $\mathrm{O}_{2}$ produzindo radicais livres, como superóxido $\left(\mathrm{O}_{2}\right)$, podendo destruir os pigmentos. Há algumas defesas bioquímicas utilizadas pelas plantas, como a enzima superóxido dismutase (SOD) que destrói os radicais livres. No entanto estas defesas são insuficientes se a exposição à alta luminosidade é prolongada (TAIZ \& ZIEGER, 2004).

O ambiente de luz em que a planta cresce é de fundamental importância, pois a adaptação das plantas a este ambiente depende do ajuste de seu sistema fotossintético, de modo que a luminosidade

Ciência Rural, v.35, n.3, mai-jun, 2005. 
ambiental seja utilizada de maneira mais eficiente possível. As respostas destas adaptações serão refletidas no crescimento global da planta (ENGEL \& POGGIANI, 1991). As plantas que crescem em ambientes com muita luz têm frequentemente características estruturais e químicas que reduzem a quantidade de luz que alcança o cloroplasto. As reações de luz são componentes eficientes do sistema bioquímico. Nestas reações, até $20 \%$ da luz absorvida pode ser convertida em energia utilizável, ATP (TAIZ \& ZIEGER, 2004).

Os efeitos da luz em alimentos têm sido estudados intensamente (BEKBOK LET, 1990). No entanto, os efeitos dos filtros óticos em embalagens, especialmente a respeito do comprimento de onda, ainda não estão elucidados. Um estudo em filtros UV estabeleceu somente um pequeno efeito protetor para alimentos sensíveis (RIEBLINGER et al., 1998). Através de uma patente, o uso de sensibilizantes naturais (clorofila, riboflavina) é recomendado para embalagens transparentes coloridas (INTERNATIONAL PATENT, 2001).

\section{Clorofilas como corantes em alimentos}

As clorofilas são pigmentos verdes muito comuns em legumes e em várias frutas. Devido a sua cor e as propriedades físico-químicas, são também usadas como aditivos para produtos alimentícios. Estes pigmentos são quimicamente instáveis e podem ser alterados ou destruídos facilmente, modificando a percepção e a qualidade dos produtos. Em geral, as clorofilas são relativamente instáveis e sensíveis à luz, aquecimento, oxigênio e a degradação química (SCHOEFS, 2002).

Os pigmentos fotossintéticos, presentes nos cloroplastos, não podem ser sintetizados por tecidos animais. Entretanto, células animais podem modificálos quimicamente para assimilação, e estas moléculas devem ser obtidas dos alimentos. As clorofilas são também usadas como corantes naturais e antioxidantes para restabelecer o teor natural destas moléculas em produtos alimentares ou para preparar produtos enriquecidos. Tais pigmentos podem ser quimicamente modificados antes de serem incorporados aos alimentos, como, por exemplo, substituindo o $\mathrm{Mg}^{2+}$ por $\mathrm{Cu}^{2+}$ na clorofila. Precursores e derivados das clorofilas também são usados na medicina para tratamentos fotodinâmicos (BRITTON, 1995; SCHOEFS, 2002).

As opções naturais começam a ganhar mais mercado com o veto crescente aos corantes sintéticos para alimentos. A clorofila, utilizada de modo esporádico no Brasil, é importada de fábricas de grupos na Europa, de onde é extraída da alfafa.
Este corante, quando 100\% clorofila, não é estável. Devido a este motivo, a clorofila sofre alteração na sua molécula, substituindo o átomo de magnésio por cobre, originando a chamada clorofilina cúprica, a qual é estável e pode ser utilizada em formulações hidro ou lipossolúveis. Mesmo assim, a clorofilina cúprica tem mercado limitado no Brasil. Uma curiosidade, em relação a este corante, é ele não ser considerado natural nos Estados Unidos, em razão da alteração da molécula (FURTADO, 2004).

Degradação da clorofila em alimentos

A degradação das clorofilas resulta na formação de cinco grupos de compostos intermediários, com um deles julgando-se ser o produto final. A razão para essa classificação em grupos maiores e não em compostos individuais é devido à extremidade da cadeia da clorofila ser frequentemente substituída por grupos diferentes, sendo, possivelmente, o resultado de fatores ambientais, como o pH e alterações enzimáticas (HEATON et al., 1996).

A decomposição das clorofilas durante a senescência faz parte do desenvolvimento da planta e conduz a acumulação de catabólitos incolores. A perda do pigmento verde ocorre devido à quebra oxigenolítica do macrociclo porfirínico do feoforbídeo seguido por uma redução na intensidade fluorescente do catabólito da clorofila. Este é um processo que envolve a interação de duas enzimas, a "feoforbídeo $a$ oxigenase" $(\mathrm{PaO})$ e a enzima "redutase da via dependente da ferrodopina” (RCCR). A atividade da PaO é encontrada somente durante a senescência e parece ser um regulador chave do catabolismo das clorofilas (PRUZINSKÁ et al., 2003).

A etapa inicial da degradação das clorofilas em tecidos senescentes é iniciada por fatores externos, como o estresse hídrico, luminosidade, alterações térmicas, níveis aumentados de etileno ou a combinação destes fatores (HEATON \& MARANGONI, 1996). Como citado anteriormente, a decomposição das clorofilas em alimentos processados inicia-se com o rompimento de tecido pelas forças externas do processamento. Isto resulta em alterações químicas, enzimáticas e, possivelmente de expressão gênica, que conduzem a uma redução da concentração de clorofilas (HEATON et al., 1996). Segundo pesquisas realizadas, as hidrólises das clorofilas e da clorofilase podem ser evitadas devido ao fato de estarem separadas espacialmente (PRUZINKÁ et al., 2003).

A decomposição das clorofilas $a$ e $b$ foram muito menores a baixas temperaturas (LISIEWSKA et 
al., 1997). A perda de cor durante o armazenamento sob congelamento é atribuída ao desvanecimento da cor verde vívida da clorofila a uma marrom azeitona, característica da feofitina. (HEATON et al., 1996). Este fenômeno é conhecido como feofitinização, onde o magnésio do centro da molécula de clorofila é substituído por hidrogênio. Outro tipo comum de deterioração é a remoção da cadeia fitol, conduzindo à formação de clorofilida ou feoforbídeo. Devido às taxas que levam à reação de feofitinização serem, geralmente, mais elevadas que outras vias de degradação da clorofila, elas são consideradas o mecanismo mais importante de destruição de clorofila durante o processamento de alimentos. Durante o armazenamento sob congelamento, as baixas temperaturas aumentam a tendência de precipitação de proteínas dos alimentos por provocarem a diminuição do $\mathrm{pH}$, ampliando as taxas de reações de catálises ácidas, como a feofitinização (MARTINS \& SILVA, 2002).

A decomposição das clorofilas é afetada pelo $\mathrm{pH}$ dos tecidos. O pH básico $(9,0)$ torna a clorofila mais estável ao calor, quando comparada ao pH ácido $(3,0)$. Os íons positivos minimizam a permeabilidade da membrana, que entra em equilíbrio com as cargas negativas diminuindo, dessa forma, a degradação das clorofilas (VON ELBE, 2000). Essa instabilidade da molécula pode alterar a sua cor, o valor comercial e as qualidades nutritivas, levando também a uma impressão negativa do produto (SHOEFS, 2002).

Em uma escala global, a decomposição das clorofilas em sistemas aquáticos é, ao menos, quantitativamente e ecologicamente tão significante quanto em ambientes terrestres. A estimação apurada das clorofilas é essencial em estudos da ecologia aquática e, como as clorofilas e a clorofilida exibem as mesmas propriedades espectrais, as produções destes derivados podem seriamente alterar estimativas feitas com métodos espectrofotométricos empregados em estudos oceanográfícos (THOMAS et al., 2001). O esquema da degradação das clorofilas está representado na figura 2.

\section{Processamento}

Os pigmentos clorofilianos podem ser extraídos da planta recém colhida, porém, o método mais usual é a extração após a secagem. Isso deve ser feito sob vácuo a baixas temperaturas o mais rápido possível após a colheita, evitando sua exposição à luz. A clorofila $a$ apresenta uma cor azul- esverdeada em solução, enquanto a clorofila $b$ uma cor amareloesverdeada. Esta diferença pode ser quantificada por três métodos: espectrofotometria, fluorimetria e cromatografía líquida de alta eficiência (CLAE). A fluorimetria é mais sensível do que a espectrofotometria e requer um menor volume de amostra, podendo ser utilizada para determinações in vivo. O método por cromatografía é o mais preciso, mas não é adequado para análises de rotina (BARROSO, 1998). A atividade da clorofílase (enzima nativa) depende da presença de água, álcool, acetona e calor, além de uma temperatura ótima $\left(60-82^{\circ} \mathrm{C}\right)$, diminuindo em temperaturas maiores (acima de $80^{\circ} \mathrm{C}$, com a perda de atividade acima de $100^{\circ} \mathrm{C}$ ) (VON ELBE, 2000). Em um processo de branqueamento de folhas, através de imersão na água em ebulição, foi observada uma alta taxa de perda das clorofilas, no entanto essa taxa foi reduzida quando o pH foi ajustado para 6. (FABOYA-00,1985).

Para entender o mecanismo do efeito antioxidante das clorofilas na autoxidação de óleos sob o abrigo de luz, foram comparadas atividades antioxidantes de vários derivados das clorofílas. Outra substância analisada em relação à atividade antioxidante foi a protoporfírina metil esterase e seus compostos quelados com magnésio. A porfirina é uma estrutura química essencial para a atividade antioxidante das clorofílas, no entanto, essa substância não degradou hidroperóxidos (metabólitos de oxidação), mas reduziu radicais livres como l,ldifenil-2-picrilhidrazil. Estas observações sugerem que as clorofilas podem agir como doadoras de hidrogênio e quebrar a cadeia de reação (LUI \& CHEN, 1998).

Pesquisas realizadas com o objetivo de verificar o efeito do aquecimento na estabilidade das clorofilas em óleo de semente de algodão concluíram, através dos resultados obtidos, que as clorofilas podem ser completamente destruídas a $180^{\circ} \mathrm{C}$ por 60 minutos. Porém a taxa de formação de peróxidos foi menor do que a taxa de degradação (LUI \& CHEN, 1998).

A clorofila $a$ é mais suscetível à degradação oxidativa na presença de ácidos graxos saturados quando comparada com ácidos graxos insaturados durante o aquecimento. A presença de ácidos graxos saturados pode facilitar a formação de isômeros I e II da clorofila $a$ enquanto a presença de ácidos graxos insaturados pode facilitar a formação de clorofila a'. A clorofila $a$ é mais suscetível à degradação oxidativa e isomerização que o $\beta$-caroteno na presença de ésteres de ácidos graxos, especialmente metil estearato, durante aquecimento (LUI \& CHEN, 1998). Uma pesquisa foi realizada com o objetivo de analisar um método eletroquímico moderno para avaliar o poder antioxidante de compostos lipofílicos presentes em legumes, como carotenóides, clorofilas, tocoferóis e capsaicina. O método proposto é seletivo para compostos lipofílicos que têm poder antioxidantes 


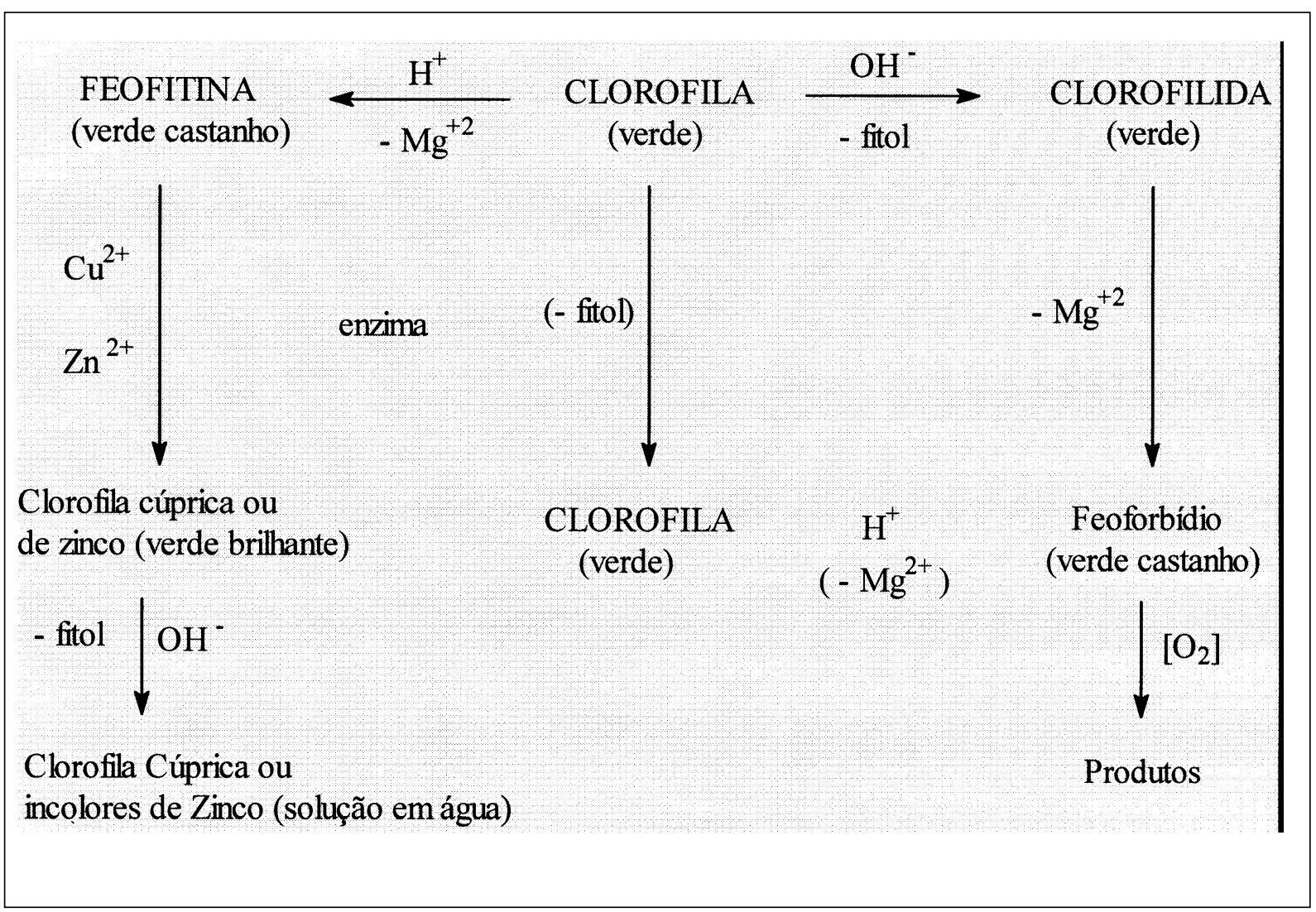

Figura 2 - Esquema de degradação da clorofila - Fonte BOBBIO, 1995.

pois, aplicado a compostos puros, resultou a ordem de poder antioxidante como segue: licopeno $>\beta-$ caroteno $>$ zeaxantina $>\alpha$-caroteno $>\beta$-criptoxantina $>$ luteina $>\alpha$-tocoferol $>$ capsaicina $>$ clorofila a $>$ clorofila $\mathrm{b}>$ astaxantina $>$ cantaxantina. (BURATTI et al., 2001).

Embora a maioria das enzimas possa ser bem preservada através de armazenamento sob congelamento, a atividade da enzima está limitada pela temperatura de armazenamento devido a mudanças físicas e químicas na fase não-congelada. Além disso, se um tratamento com branqueamento for aplicado adequadamente, a atividade enzimática durante armazenamento sob congelamento pode ser desprezível quando comparado à cor e degradação química das clorofilas (MARTINS \& SILVA, 2002).

Como esperado, a rota principal da degradação das clorofilas é por feofitinização direta ou indireta para feofitina. A perda de cor em altas temperaturas de armazenamento é principalmente atribuída ao processo de feofitinização. Em temperaturas mais baixas (temperaturas de armazenamento), a cor é estabilizada, provavelmente, pela formação de um composto metal-clorofila. A obtenção de modelos cinéticos pode descrever a cor e perdas de clorofilas com precisão durante armazenamento sob congelamento, e a dependência da temperatura da taxa de reação segue o modelo de Arrhenius (MARTINS \& SILVA, 2002).

A produção de oxigênio singleto pelas clorofilas não é restrita a extratos de pigmentos aquosos, mas também ocorre em solventes menos polares como o óleo. Por essa razão, um óleo contendo um alto conteúdo de clorofilas ou produtos da degradação deve ser estocado no escuro e em temperatura reduzida (SCHOEFS, 2002).

As radiações ionizantes e a fotosensibilização são processos altamente prejudiciais e geram radicais livres derivados de oxigênio bem como espécies excitadas. Porém, podese observar uma diferença entre os tipos e a extensão de espécies reativas de oxigênio (ROS) as quais têm sido encontradas em várias condições patológicas. Conseqüentemente, compostos naturais capazes de prevenir danos oxidativos induzidos por estes agentes podem ter aplicações potenciais. A Clorofilina, análogo 
solúvel em água da clorofila, tem sido examinada por sua habilidade em inibir danos de membrana induzida por radiação $\gamma$ e fotosensibilização envolvendo metileno azul e luz visível (BOLOOR et al., 2000).

A substituição dos pigmentos sintéticos, usados em alimentos, por pigmentos naturais será um importante passo para produzir alimentos saudáveis. Os produtos industrializados clorofíla-Mg (E 140) e clorofíla-Cu (E141) são ambos permitidos como aditivos de alimentos, embora a substância E141 tenha se mostrado mais estável do que a substância E140, levando em consideração a exposição à luz, oxigénio, temperatura, bissulfito de sódio, peróxido de benzoila e ácidos (EDER.1996).

\section{Metabolismo}

A deterioração oxidativa de lipídios, vitaminas, proteínas e pigmentos naturais resultam na perda de aroma, nutrientes e cor (BEKBOK LET, 1990). O feoforbídeo é o último catabólíto intermediário de cor verde na reação (THOMAS et al., 2001). As clorofilas são degradadas a produtos incolores, expondo, dessa forma, outros pigmentos. A degradação deste pigmento ocorre dentro de um período relativamente curto de tempo em tecidos de plantas senescentes, embora os produtos intermediários e finais não tenham sido identificados in vivo (PARK et al, 1973). A senescência tem sido definida como um processo regulado geneticamente o qual leva à morte as células, órgãos, ou todos os organismos. Em plantas, a senescência é acompanhada por mudanças morfológicas e/ou alterações nas propriedades bioquímicas e biofísicas do metabolismo. A senescência nas folhas, em particular, pode envolver a degradação de proteínas, clorofilas, ácidos nucléicos e membranas seguidas pelo transporte de alguns dos produtos de degradação para outros tecidos da planta. Em frutas e legumes, a perda das clorofilas é associada a mudanças estruturais que liberam ácidos celulares e várias enzimas degradativas dos vegetais (HODGES \& FORNEY, 2000). Segundo estudos realizados, detectou-se uma perda de $95 \%$ de clorofila durante a senescência de folhas, embora nenhum produto de degradação colorido tenha sido descoberto para explicar como a folha tornou-se amarela, marrom, ou vermelha (PARK et al., 1973).

As moléculas de clorofilas possuem uma longa cadeia de duplas ligações conjugadas as quais reagem facilmente com ácido, base, oxigênio e luz. Tais moléculas reagem facilmente com $\mathrm{O}_{2}$ sob luz formando espécies de oxigênio ativas (foto-oxidação), que oxidam outras moléculas, incluindo lipídios e proteínas e, por esta razão, devem ser monitoradas durante a extração e análises (SHOEFS, 2002). Os produtos de oxidação são produzidos em alimentos que contenham gordura podendo levar a produtos com sabores indesejáveis. O hexanal, pentanal ou pentano são considerados analiticamente indicadores de oxidação de lipídios (WU et al., 1998).

\section{CONCLUSÕES}

A intensidade de absorção de luz realizada pela planta dependerá do ambiente na qual a mesma se encontra. O excesso de luz ativará um mecanismo que diminuirá a sua absorção com o objetivo de proteger a planta podendo inibir a fotossíntese através de dois processos: fotoinibição (reversível) e fotooxidação (irreversível). Pelo fato de as clorofilas serem pigmentos instáveis, incluindo fatores ambientais, como o estresse hídrico, $\mathrm{pH}$, luminosidade reduzida, alterações enzimáticas, temperatura e aumento do etileno, cuidados individuais devem ser tomados durante a extração e análise, assim como, no decorrer do processamento dos alimentos, com o objetivo de manter a integridade da molécula de clorofila. Todas as manipulações devem, obrigatoriamente, serem conduzidas rapidamente e em ambiente de pouca luz ou no escuro, para evitar o foto-branqueamento. Outro fator a ser considerado é evitar ao máximo o superaquecimento e a oxidação dos alimentos, e as enzimas nativas devem ser inativadas, impedindo, desta forma, que as reações metabólicas ocorram, retardando a degradação da clorofila. As clorofilas são muito utilizadas como pigmentos e antioxidantes. Sua atividade antioxidante foi observada em derivados da clorofila como em protoporfirino/metilesterase e compostos quelados com $\mathrm{Mg}^{+2}$. A substituição dos pigmentos sintéticos pela clorofila contribuirá muito para a produção de alimentos mais saudáveis.

\section{REFERENCIASBIBLIOGRÁFICAS}

BEKBOG LET, M. Light effects on food. Journal of Food Protection, v.53, p.430-440, 1990.

BARRoso, G.F. BMLP - Programa Brasileiro de Intercâmbio em Maricultura. Programa de Monitoramento Ambiental. Protocolo para Análise de clorofila $a$ e feopigmentos pelo método fluorímétro TD700. Vitória, Espírito Santo, 1998. p.1-21.

BOLOOR, K.K. et al. Chiorophyilin as a protector of mitochondrial membranes against y-radiation and photosensitizatíon. Toxicology, v.155, p.63-71, 2000.

BRITTON, G. UV/ visible spectroscopy. In: BRITTON, G. et al. (Eds). Carotenoids, spectroscopy. Birkhauser, 1995. V.1, p.13-62.

Ciência Rural, v.35, n.3, mai-jun, 2005. 
BURATTI, S. et al. Rapid electrochemical method for the evaluation of the antioxidant power of some lipophilic food extracts. Journal of Agriculture and Food Chemistry, v.49, n.11, p.5136-5141, 2001.

EDER, R. Pigments. In: NOLLET, L.M. Handbook of food analysis: physicalcharacterization and nutrient analysis, v.l, cap.23, p.95 2-968, 1996.

ENGEL, V.L.; POGGIANI, F. Estudo da concentração de clorofila nas folhas e seu espectro de absorção de luz em função do sombreamento em mudas de quatro espécies florestais nativas. Revista Brasileira de Fisiologia, Londrina, v.3, n.1, p.39-45, 1991

FABOYA-00. Chlorophyll changes in some green leafy vegetables during cooking. Journal of the Science of Food and Agriculture, v.36, n.8, p.740-744, 1985.

FURTADO, M. Corantes: indústria de alimentos adere aos corantes naturais. Capturado em 27 maio 2004. Online. Disponível em http:// www.quimica.com.br/revista /qd421/ corantesl.htm.

HEATON, J.W.; MARANGONI, A.G. Chlorophyll degradation in processed foods and senescent plant tíssues. Trends in Foods Science \& Technology, v.7, p.8-15, 1996.

HEATON, J.W. et al. Kinetic model for chlorophyll degradation in green tissue. Journal of Agricultural Food Chemistry, v.44, p.399-402, 1996.

HENDRY, G.A.F.; PRICE, A.H. Stress indicators: chlorophylls and carotenoids. In: HENDRY, G.A.F.; GRIME J.P. (Eds.) Methods in comparative plant ecology. London : Chapman \& Hall, 1993. p.148-152.

HODGES, D.M.; FORNEY, C.F. The effects of ethylene, depressed oxygen and elevated carbon dioxide on antioxidant profiles of senescing spinach leaves. Journal of Experimental Botany, v.51, n.344, p.645-655, 2000.

INTERNATIONAL PATENT CLAIM PCT/EP01/01524 (13.02.2001): Mit Farbstofen gefãrbte, transparente oder teiltransparente Packstofe.

KLUGE, R.A. LCB - 311, Fisiologia vegetal: apontamentos de aulas teóricas de fotossíntese. ESALQ/USP. Capturado em 22 mar. 2004. Online. Disponível em Internet http: // orion.cpa. unicamp.br/ sbfv / arquivos/aulas/gradOl/06 fotoquímica da fotossintese/ fotossínteseKluge.

LISIEWSKA, Z. et al. Effect of conditions and time of storage on technological quality changes of parsley leaves. FoliaHorticulturae, v.9, n.2, p.21-29,1997.

LUI, M.H.; CHEN, B.H. Relationship between chlorophyll $a$ and $\beta$-carotene in a lipid-containing model system during heating. Food Chemistry, v.61, n.1/2, p. 41-47,1998.

MARTINS, R.C.; SILVA, C.L.M. Modelling colour and chlorophyll losses of frozen green beans (Phaseolus vulgaris. L.). International Journal of Refrigeration, v.25, p.966-974, 2002.
MUSSI, L. Eficiência fotodinâmica das protoporfirinas IX de magnésio e zinco. 2003. 73p. Dissertação (Mestrado em Química) - Curso de Pós-graduação em Química, Instituto de Química, Unicamp.

OKADA, K. et al. Effects of light on degradation of chlorophyll and proteins during senescence of detached rice leaves. Plant cell physiology, v.33, n.8, p.1183-1191, 1992.

PARK, Y. et al. On chlorophyll breakdown in senescent leaves. Journal Agriculture and Food Chemistry, v.21, p.279, 1973.

PRUZINSKA, A. et al. Chlorophyll breakdown: Pheophorbide a oxygenase is a rieke-type iron- sulfur protein, encoded by the accelerated cell death 1 gene. Plant Biology, v.100, n.25, december, 2003.

RAFAEL S.D. Effect of storage time-food processing plants and marketing conditions on the quality ofsome frozen vegetables. 1992. PhD thesis, University of Alexandria, Egypt.

RIEBLINGER, K. et al. Lichtschutz für lebensmittel. Zeitschrift fiir die lebensmittelwirtschaft, v.49, p.36-38, 1998.

ROMANO, M.R. Análise de crescimento, produção de biomassa, fotossíntese, e biossíntese de aminoácidos em plantas transgênicas de tabaco (Nicotiana tabacum L.) que expressam o gene $L h \boldsymbol{c b} 1 * \mathbf{2}$ de ervilha. 2001. 66f. Dissertação (Mestrado em Ciências, área de concentração: Fisiologia e Bioquímica de plantas) - Esalq / USP.

SCHOEFS B. Chlorophyll and carotenoid analysis in food products. Properties of the pigments and methods of analysis. Trends in Food Science \& Technology, v.13, p.361-371, 2002.

TAIZ, L.; ZIEGLER, E. Fisiologia vegetal. 3.ed. Porto Alegre : Artmed, 2004. p.693. (Trad. SANTARÉM E.R. et al.).

TANAKA, A. et al. Chlorophyll $a$ oxygenase (CAO) is involved in chlorophyll $b$ formation from chlorophyll $a$. Plant Biology, v.95, p.12719-12723, 1998.

THOMAS, H. et al. Recent advances in the cell biology of chlorophyll catabolism. Advances in Botanical Research, v.35, p.1-52, 2001.

VIEIRA, G. Gap dynamics in managed Amazonian forest: Structural and ecophysiological aspects. 1996. 162f. Tese (Doutorado em Ecologia Tropical) - University of Oxford, Grã-Bretanha.

VON ELBE J.H. Colorantes. In: FENNEMA, O.W. Química de los alimentos. 2.ed. Zaragoza : Wisconsin - Madison, 2000. Cap.10, p.782-799.

WU, Y. et al. Factors electing static headspace gaschromatographic analysis of lipid oxidation in precooked meat. Journal of Agricultural and Food Chemistry, v.46, p.3677-3682,1998.

$\mathrm{XU}, \mathrm{H}$. et al. Chlorophyll $b$ can serve as the major pigment in functional photosystem II complexos of cyanobacteria. Proceedings of the National Academy of Sciences, v.98, n.24, november, 2001. 